\begin{abstract}
Iranica
Abstracta Iranica Revue bibliographique pour le domaine irano-aryen

Volume 37-38-39 | 2018

Comptes rendus des publications de 2014-2016
\end{abstract}

\title{
Manfred Hutter. Iranische Personennamen in der hebräischen Bibel
}

Florence Jullien

\section{(2) OpenEdition \\ 12 Journals}

\section{Édition électronique}

URL : http://journals.openedition.org/abstractairanica/42974

DOI : 10.4000/abstractairanica.42974

ISBN : 1961-960X

ISSN : 1961-960X

Éditeur :

CNRS (UMR 7528 Mondes iraniens et indiens), Éditions de l'IFRI

Référence électronique

Florence Jullien, « Manfred Hutter. Iranische Personennamen in der hebräischen Bibel », Abstracta Iranica [En ligne], Volume 37-38-39 | 2018, document 4, mis en ligne le 30 décembre 2018, consulté le 28 septembre 2020. URL : http://journals.openedition.org/abstractairanica/42974 ; DOI : https://doi.org/ 10.4000/abstractairanica.42974

Ce document a été généré automatiquement le 28 septembre 2020

Tous droits réservés 


\title{
Manfred Hutter. Iranische Personennamen in der hebräischen Bibel
}

\author{
Florence Jullien
}

\section{RÉFÉRENCE}

Manfred Hutter. Iranische Personennamen in der hebräischen Bibel. (Iranisches

Personennamenbuch Band 7/Faszikel 2 ; Sitzungsberichte der phil.-hist. Klasse 860 ;

Iranische Onomastik 14), Wien, 2015, 83 p. ISBN 978-3-7001-7593-3.

1 Ce petit fascicule fait désormais référence pour les interprétations des noms propres iraniens en hébreu biblique, après les études entreprises à la fin du 19e-début du 20e siècle (F. Justi, I. Scheftelowitz). Au total, 71 noms sont ainsi discutés : 54 noms de la Bible hébraïque dérivant des langues iraniennes sont répertoriés, comprenant aussi les patronymes araméens d'origine iranienne avérée ou supposée ; plusieurs étymologies (17) jusqu'ici proposées comme iraniennes sont critiquées et écartées. Chaque entrée fait l'objet de courtes précisions prosopographiques, suivies d'une discussion étayée des interprétations étymologiques. L'A. fournit également les références bibliques pour chacune des entrées ainsi que la forme du nom dans la Septante. De précieux indices ont été établis - outils commodes requis dans cette collection. 


\section{AUTEURS}

\section{FLORENCE JULLIEN}

CNRS, Mondes iranien et indien, Paris 